\title{
Hydroelectric Plants and Dams as Industrial Heritage in the Context of Nature-Culture Interrelation: An Overview of Examples in Turkey
}

\author{
Nurdan Kuban (D)
}

check for updates

Citation: Kuban, N. Hydroelectric Plants and Dams as Industrial Heritage in the Context of Nature-Culture Interrelation: An Overview of Examples in Turkey. Energies 2021, 14, 1281. https:// doi.org/10.3390/en14051281

Academic Editor: Epari Ritesh Patro

Received: 19 February 2021

Accepted: 23 February 2021

Published: 26 February 2021

Publisher's Note: MDPI stays neutral with regard to jurisdictional claims in published maps and institutional affiliations.

Copyright: (C) 2021 by the author. Licensee MDPI, Basel, Switzerland. This article is an open access article distributed under the terms and conditions of the Creative Commons Attribution (CC BY) license (https:/ / creativecommons.org/licenses/by/ $4.0 /)$.
Department of Architecture, Kocaeli University, İzmit 41300, Kocaeli, Turkey; nnkuban@gmail.com

\begin{abstract}
The article investigates nature-culture interrelation over the case studies of hydroelectric plants of the 20th century. In many cases, construction of these structures has evidently resulted in irreversible changes in natural and cultural environments. However, they have also supplied energy for the industrialization of civilizations. After approximately 100 years of existence, it is crucial to determine the future of these hydroelectric facilities, which are artifacts of industrial heritage approaching the end of their productive life spans. The article proposes an analytical approach aiming to sustain the integrity of nature and culture in the conservation of hydroelectric plants, presenting these energy facilities as cultural properties of industrial heritage, and discussing the impact of hydroelectric dams on natural and cultural environments, along with the effects of nature in the deterioration of these structures in order to pave the way to an optimized and sustainable future for the heritage of energy.
\end{abstract}

Keywords: nature-culture; hydroelectric plants; dams; industrial heritage

\section{Introduction}

Due to the climate crisis and global disasters, environmental sustainability is on the agenda as one of the most important contemporary goals. It is of great importance to preserve nature for future generations while taking measures such as mitigating water crises and providing the necessary energy for the continuity of human life and culture. Dams and hydroelectric power plants create a dilemmatic focus in the discussion. On the one hand, they are considered in 'the clean energy' group because they utilize the power of water as one of the natural resources, and on the other hand, they are approached with suspicion since they seriously transform the natural territories where they are constructed.

Murray Bookchin, as a pioneer in the environmental movement, expresses his opinion on how anomalous a conflict it is that: "Even such a wayward cult hero as Woody Guthrie once celebrated the huge dams and giant mills that have now earned so much opprobrium" [1]. However, in the same essay, within his explanations on "high or hard" technologies in comparison to "appropriate or soft" technologies, Bookchin lists 'hydraulic sources of energy' under the category of "appropriate or soft" technologies. The dilemma is that hydropower is considered among types of renewable energy depending on its natural source and non-polluting method of energy production; however, mega-dams are frequently criticized for disrupting waterways and negatively affecting aquatic environments by altering water levels, currents, and migration paths for freshwater ecosystems.

Another dilemma is that examples of these structures, which were built in the past as the most modern and technological engineering/architectural structures of their time, are currently considered as industrial heritage. Such structures and the territories they create in their surroundings constitute components of cultural heritage, which should be transferred to future generations as energy facilities of an early engineering era and human-intervened natural territories in the context of cultural landscapes. 
In the context of inter-disciplinary studies, this article aims to reveal the standpoint of the cultural heritage field. Thus, rather than addressing issues of constructing new hydro-electric facilities, the study discusses the management and monitoring of facilities constructed in the past centuries. The main objectives of this study are: To present an alternative perspective of nature-culture interrelation over the case study of hydro-electric facilities; to emphasize the value of dams and hydro-electric plants as industrial heritage; to discuss the mutual deteriorating effects of nature and hydroelectric plants in order to reveal possible constraints. Thus, the article focuses on the hydroelectric plants of the past, with a specific emphasis on culture-nature interrelation in the context of environmental sustainability. Hydroelectric facilities of the 20th century are discussed as cultural properties of industrial heritage. Impacts of hydroelectric plants on surrounding cultural and natural properties are introduced; moreover - with a twist of cons and pros-the impacts of nature on these facilities are also examined in detail, in order to pave the way to an optimized and a sustainable future for the heritage of energy.

\section{Objectives and Methodology of the Study}

The main objective of the study is to specify measures ensuring the efficient and sustainable relationship of hydroelectric plants with their natural and cultural environments throughout their entire existence. In order to reach this goal, two sub-goals are defined: To discuss the mutual relationship of hydroelectric plants with natural and cultural environments and to discuss hydroelectric plants of the past centuries as components of industrial heritage. Work-packages are assigned for each sub-goal, and the methodology and the outputs of each work-package are indicated in Table 1.

The first sub-goal (discussion on the mutual relationship of hydroelectric plants with natural and cultural environments) is approached within two main work-packages: The impact of hydroelectric plants on their environments and vice-versa. Methodology utilized for work-package 1.1 (research on hydroelectric plants as a source of renewable energy and tools for sustainable development) includes a literature review and consultations with experts. The outputs of the work-package are explained in Section 3. In order to accomplish work-package 1.2 (research on tendencies for dam removals for ecological rehabilitation), a literature review and consultations with experts were carried out. The results of the workpackage are explained in Sections 3 and 4.3. A literature review was held for work-package 1.3 (research on measures for mitigating negative ecological impacts of hydroelectric plants). The discussion on the work-package is held in Section 3. Work-package 1.4 includes the research on dams displacing settlements of cultural/historical value, conducted through a literature review and site visits. The results of the work-package are presented in Section 3.

Work-package 2 searches for the impacts of nature on hydroelectric plants. Workpackage 2.1 consists of the research on examples of hydroelectric plants at various stages of their lives. For this study, 29 examples from different parts of the world were collected to evaluate their current conditions. Two hundred and twenty-nine hydroelectric plants in Italy and 113 facilities in Turkey were scanned in terms of construction dates and current phases. The results of WP 2.1 are utilized in the discussion held in Section 4. WP 2.2, which includes the research on dam failures, is based on a literature review and site visits, and Section 4.2 is based on this WP. Aging of hydroelectric plants was studied in WP 2.3, using the methodology of a literature review and site visits, and the results are explained in Section 4.2 .

In the main objective, it is crucial that the emphasis is made on the point that the discussion is held over 'the entire existence' of hydroelectric plants. Since the author's field of expertise is 'the conservation of cultural heritage,' as stated above: Rather than the construction of new hydroelectric plants, the article focuses mainly on the hydroelectric plants of the past century - the functional presence of which are being questioned in terms of their productive efficiencies and relationships with their natural surroundings. These structures, built with the highest technologies of the past, contemporarily bear the properties of industrial heritage. In this context, beyond merely meeting the energy requirements, 
the transfer of these facilities to the future is essential for the preservation of natural and cultural environments as they constitute cultural landscapes of industrial heritage. Conservation and adaptive re-use appear to present an opportunity of a sustainable future for structures of hydroelectric plants at the end of their productive lifespans. Therefore, the second sub-goal of the article is defined as the discussion on hydroelectric plants of the past centuries as components of industrial heritage.

Table 1. Objectives, methodology, and outputs of the study.

\begin{tabular}{|c|c|c|c|c|}
\hline Sub-Goals & Work Packages & Methodology & Outputs & \\
\hline \multirow{9}{*}{$\begin{array}{l}\text { to discuss the mutual } \\
\text { relationship of HEP } \\
\text { with natural and } \\
\text { cultural environments }\end{array}$} & \multicolumn{3}{|c|}{ 1. research on the positive/negative impacts of HEP on natural/cutural environments } & \multirow{14}{*}{$\begin{array}{l}\text { Flowchart } \\
\text { Discussion } \\
\text { Conclusion }\end{array}$} \\
\hline & $\begin{array}{l}\text { 1.1. research on hydroelectric } \\
\text { plants as a source of clean energy } \\
\text { and tools for sustainable } \\
\text { development }\end{array}$ & $\begin{array}{l}\text { literature review } \\
\text { consultations with } \\
\text { experts }\end{array}$ & Section 3 & \\
\hline & $\begin{array}{l}\text { 1.2. research on tendencies for } \\
\text { dam removals for ecological } \\
\text { rehabilitation }\end{array}$ & $\begin{array}{l}\text { literature review } \\
\text { consultations with } \\
\text { experts }\end{array}$ & Sections 3 and 4.3 & \\
\hline & $\begin{array}{l}\text { 1.3. research on measures for } \\
\text { mitigating negative ecological } \\
\text { impacts of HEP }\end{array}$ & literature review & Section 3 & \\
\hline & $\begin{array}{l}\text { 1.4. research on dams displacing } \\
\text { settlements of cultural/historical } \\
\text { value }\end{array}$ & $\begin{array}{l}\text { literature reviewsite } \\
\text { visits }\end{array}$ & Section 3 & \\
\hline & 2. research on & impacts of nature on & & \\
\hline & $\begin{array}{l}\text { 2.1. research on examples of HEP } \\
\text { at various stages of their lives }\end{array}$ & literature review & Section 4 & \\
\hline & 2.2. research on dam failures & $\begin{array}{l}\text { literature reviewsite } \\
\text { visits }\end{array}$ & Section 4.1 & \\
\hline & 2.3. research on the aging of HEP & $\begin{array}{l}\text { literature reviewsite } \\
\text { visits }\end{array}$ & Section 4.2 & \\
\hline \multirow{5}{*}{$\begin{array}{l}\text { to discuss HEPs of the } \\
\text { past centuries as } \\
\text { components of } \\
\text { industrial heritage }\end{array}$} & $\begin{array}{l}\text { 3. research on the proper- } \\
\text { ties/types/criteria/principles of } \\
\text { industrial heritage }\end{array}$ & literature review & Section 2 & \\
\hline & \multicolumn{3}{|c|}{ 4. research on HEP as industrial heritage } & \\
\hline & $\begin{array}{l}\text { 4.1. research on the architectural } \\
\text { evolution of HEP }\end{array}$ & $\begin{array}{c}\text { literature reviewsite } \\
\text { visits }\end{array}$ & Section 2 & \\
\hline & $\begin{array}{l}\text { 4.2. research on the industrial } \\
\text { heritage criteria for HEP }\end{array}$ & $\begin{array}{l}\text { literature review } \\
\text { consultations with } \\
\text { experts }\end{array}$ & Section 2 & \\
\hline & $\begin{array}{l}\text { 4.3. research on potential } \\
\text { conservation approaches } \\
\text { (continuation of } \\
\text { function/re-functioning) }\end{array}$ & $\begin{array}{l}\text { literature review } \\
\text { consultations with } \\
\text { expertssite visits }\end{array}$ & Section 2 & \\
\hline
\end{tabular}

WP 3, presented in Section 2, consists of a research on the properties/types/criteria/ principles of industrial heritage. The work-package is based on a literature review and the professional expertise of the author. WP4 aims to discuss hydroelectric plants as components of industrial heritage through 3 subtitles. WP 4.1 presents the architectural evolution of hydroelectric plants through a literature review and site visits, and the results are explained in Section 2. WP 4.2 analyzes the industrial heritage criteria for hydroelectric plants, based on a literature review, consultations with experts, and the professional expertise of the author. WP 4.3 searches for potential conservation approaches (contin- 
uation of function/re-functioning) for hydroelectric plants, based on a literature review, consultations with experts, and the professional expertise of the author, and the results are presented in Section 2.

As a result of the work-packages, a flowchart throughout the lifespan of hydroelectric plants, including opportunities, threats, and measures for the mitigation of threats is presented in Section 5. The flowchart reveals different phases of hydroelectric plants in terms of their relationships with the surrounding natural and cultural environment. The discussion is focused especially on the final stage of hydroelectric plants, offering the opportunity of preserving them as industrial heritage for future generations.

\section{Hydroelectric Plants and Dams as Industrial Heritage}

Methods to utilize natural powers had been discovered long before the industrial revolution. Pre-modern societies had made use of the sun, fires, waters, winds, thermal springs, muscles of domesticated animals, and other natural sources to facilitate the tasks of daily life; simple machines had been constructed for grinding grain with the power of water or wind. Since ancient times, electricity had always been present as a natural phenomenon of an intellectual curiosity, but the invention of methods to make use of this phenomenon dates to the 19th century when a rapid progress took place in the field of electrical science. The idea to combine technologies of electrical generation and hydraulics resulted in the development of hydro electrical facilities towards the end of the 19th century [2].

In hydroelectric facilities, falling or running water is utilized for rotating turbines to obtain mechanical energy, and then mechanical energy is converted to electrical energy through the use of generators. In the 19th century, early examples of hydroelectric plants were relatively small and local; each factory or atelier would build a plant for its requirements. Such plants depended on the natural course of water, utilizing the power of water, and then releasing it back to the system, and not causing drastic impacts on the natural regime. However, a stronger demand for energy arose by the 20th century, requiring more complex facilities. Seasonal fluctuations in river courses and problems of storage resulted in deficiency of energy at certain periods of the year. Therefore, it became necessary to build new plants accumulating water in large reservoirs created at high altitudes and forcing it through tunnels excavated in mountains (Figures 1 and 2) [3]. Nineteenth century plants had been constructed in continuity with the landscape; whereas hydroelectric plants constructed in early decades of the 20th century followed a monumental architectural style-in most cases, resembling castles of earlier centuries (Figure 3) [4]. After the Second World War, an even more drastic change occurred in the design of hydroelectric plants, transforming the architectural configuration and the image power plants. Rather than establishing accordance with the natural landscape or constituting relations with traditional architectural styles, new plants of the 20th century, deliberately exhibiting concrete arches, buttresses, and dams, became the symbols of human intellectual power transforming territories (Figure 4) [5]. Plants became witnesses of the hopes placed in the new energy, which was believed to lead to overcome the harsh conditions that nature had imposed in centuries. They were perceived as "crowns of a dream of progress" surrounded by a sacred aura, as if they were "cathedrals lost in the mountains" [6].

Initially, the impetus for constructing hydroelectric plants was the pursuit of energy; however, after more than 100 years of existence, having transformed natural terrains to create industrial landscapes, they have become the symbols of human intelligence in the long history of the human-nature interrelation (Figure 5). Producing electricity for high demands of energy, they have enabled the industrialization of nations. Moreover, the innovative construction systems and engineering techniques implemented at hydroelectric facilities of the past centuries and machinery installed within them constitute a significant phase in the history of technology. The debate on the conservation of hydroelectric facilities has been strongly opposed based on the argument that the industry has destroyed natural landscapes; however, currently "it is widely accepted that hydropower landscapes -where the industrial interventions have become evidence of cultural development with their 
striking impact on natural environments- constitute a component of industrial heritage in terms of knowledge of science and technology" [7] (Figures 6 and 7).

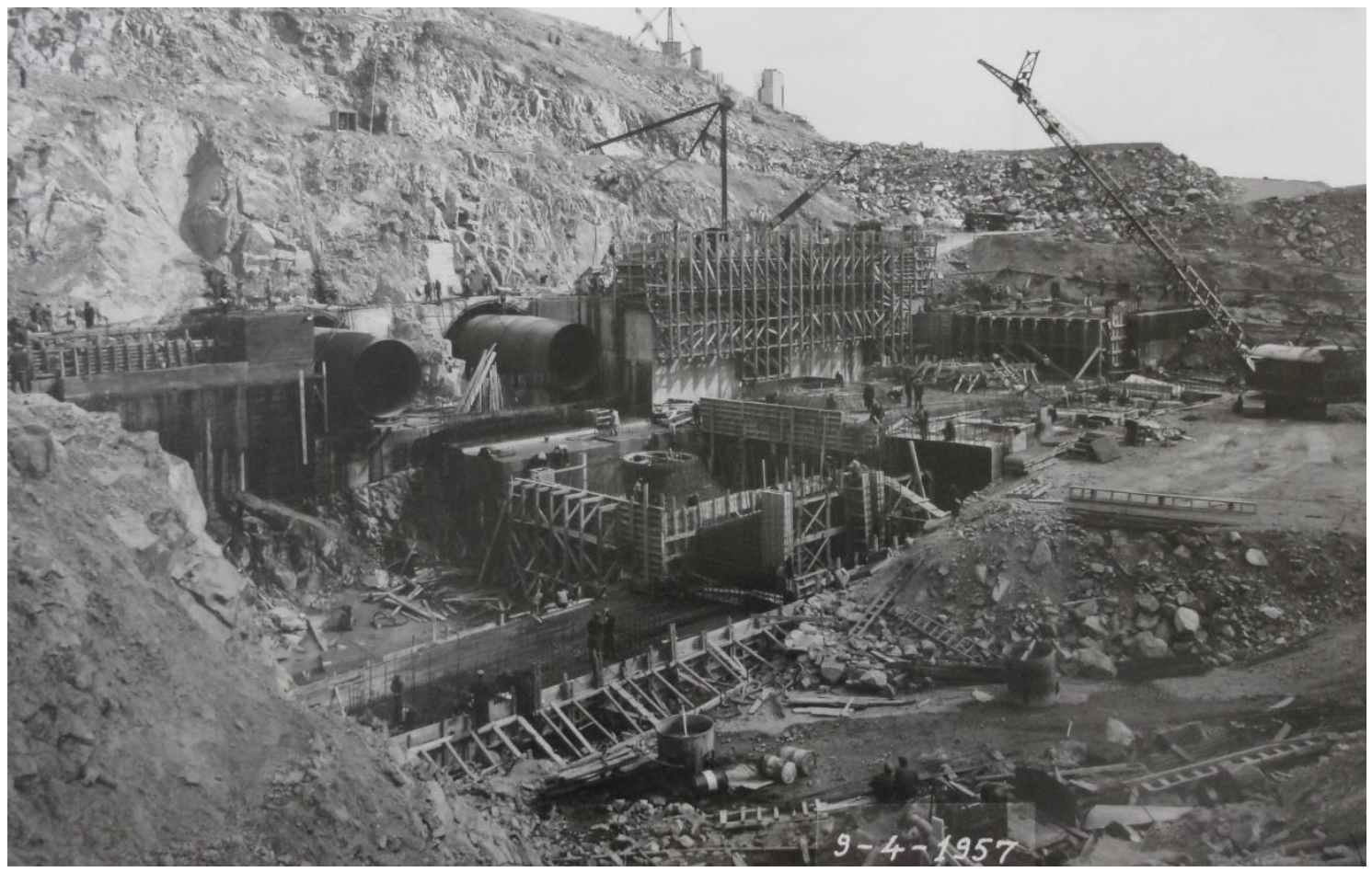

Figure 1. Construction of Hirfanlı Dam-Turkey [3].

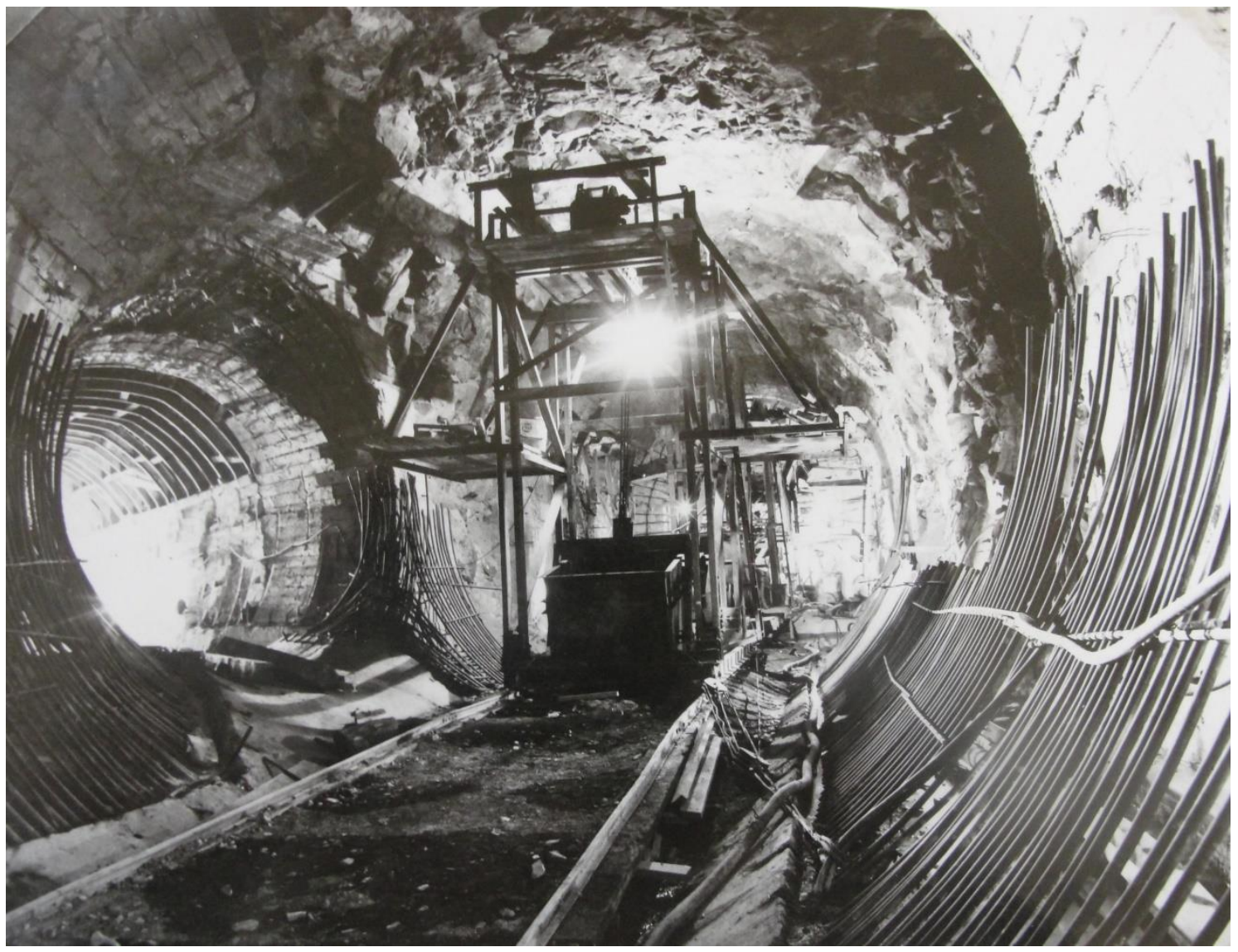

Figure 2. Construction of the power tunnels of Hirfanlı Dam-Turkey [3]. 


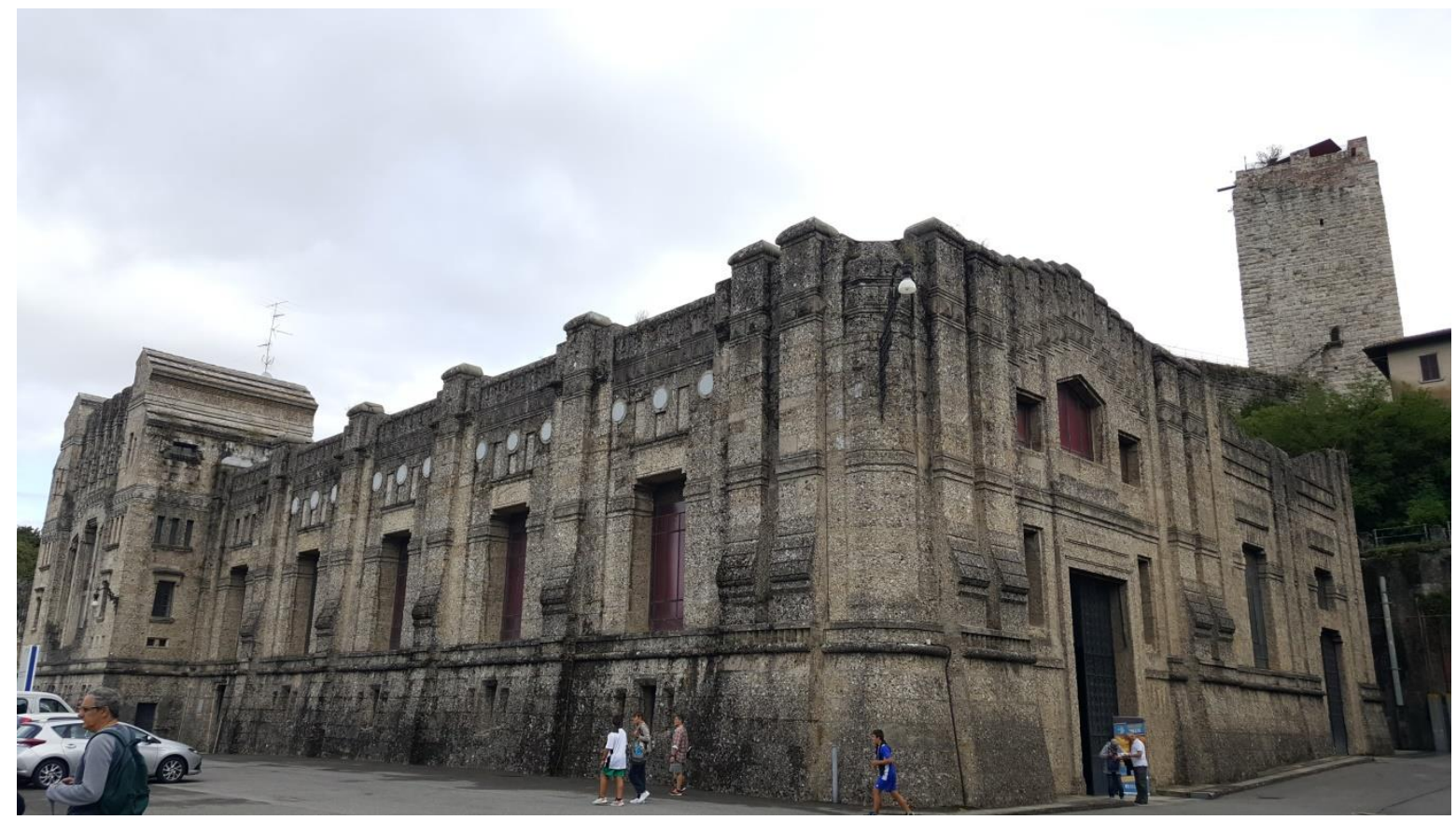

Figure 3. Taccani Hydroelectrical Power Station (built in 1906) (photo taken by the author on 9 September 2019).

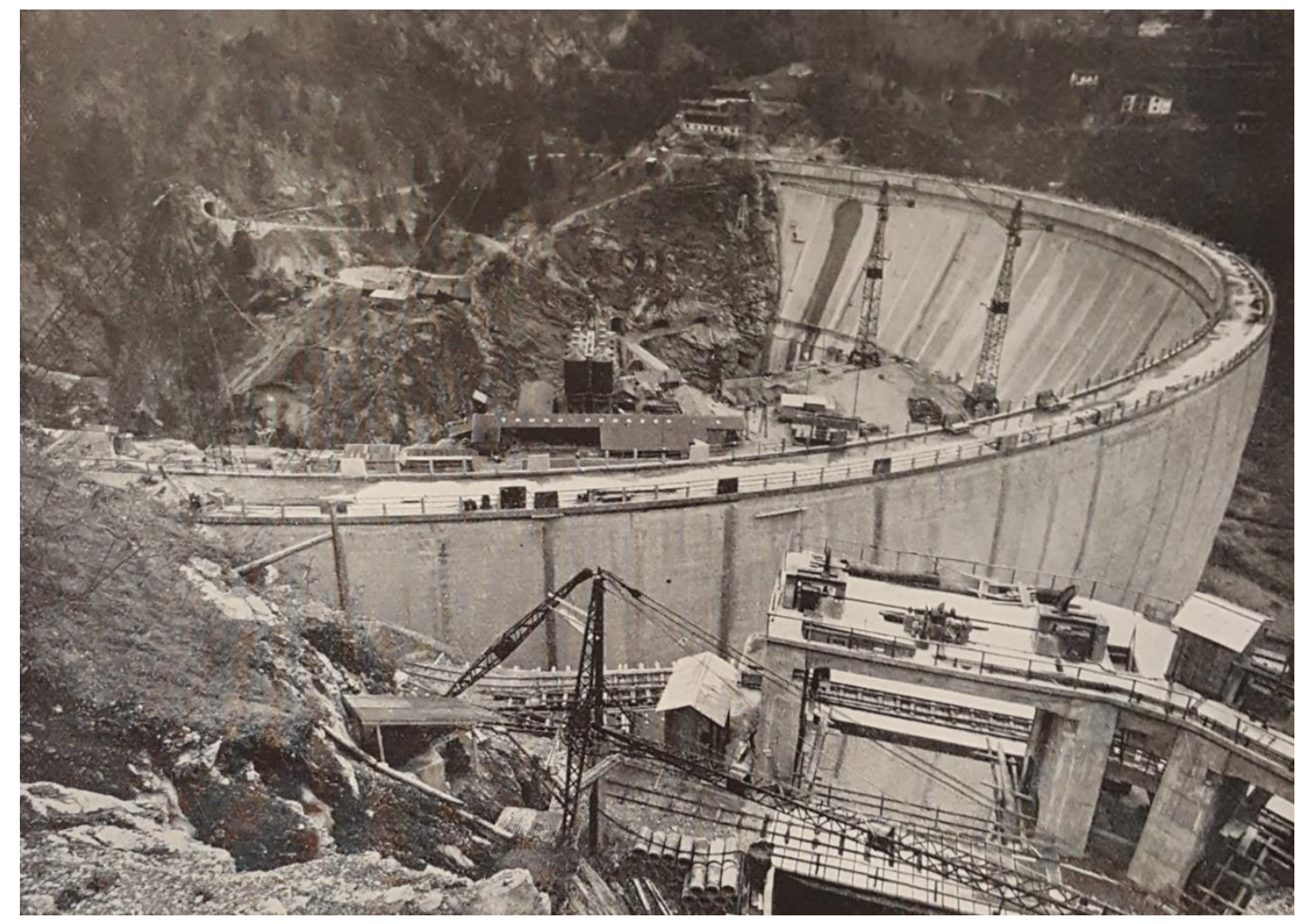

Figure 4. Construction of Pieve di Cadore Dam-Italy [5]. 


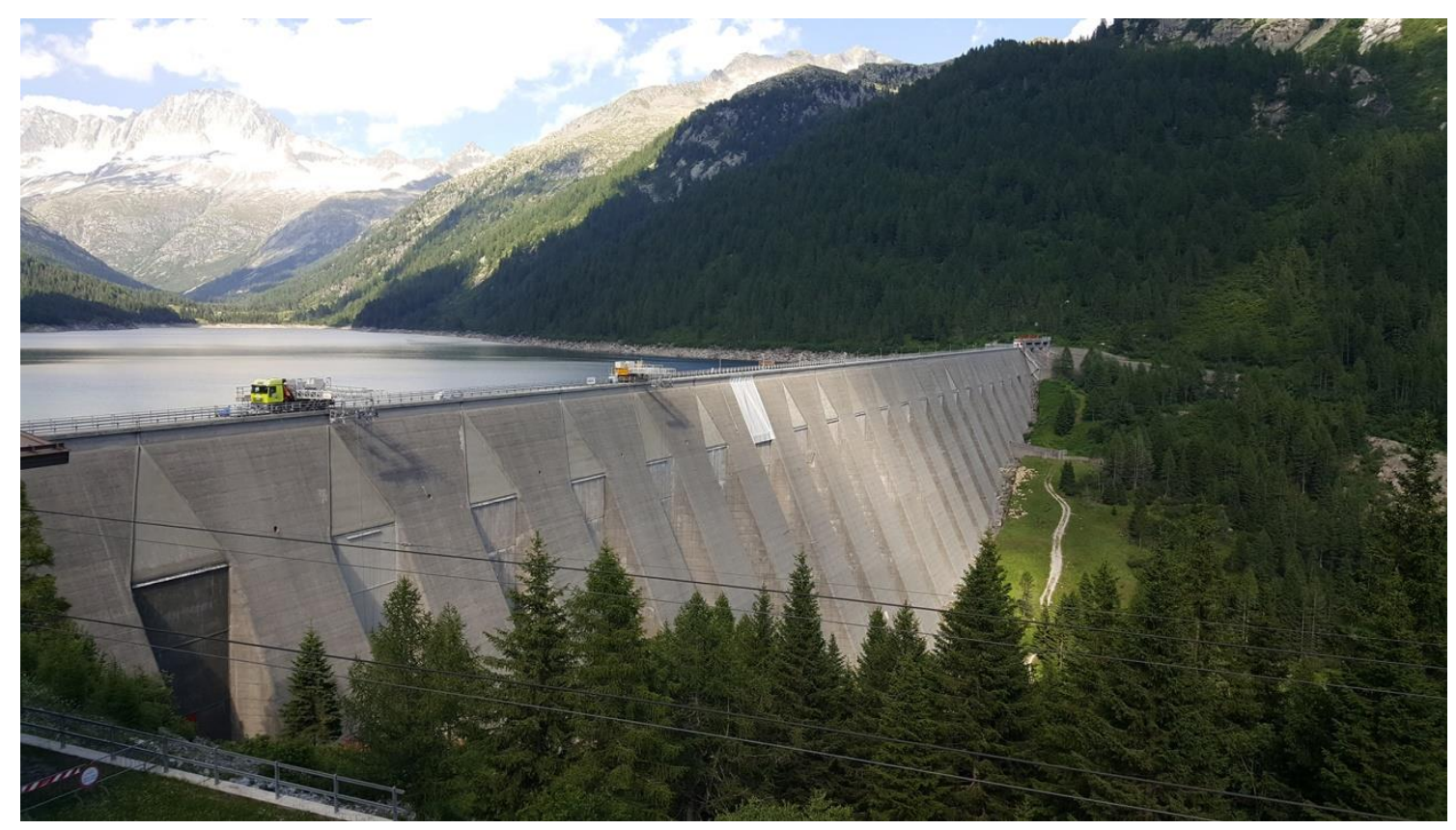

Figure 5. Bissina Dam-Italy (photo taken by the author on 5 July 2019).

Nature is the collective phenomena of the physical world, including plants, animals, and landscapes, along with other features and products of the earth. In contrast, culture is defined as the ideas, customs, social behaviors, arts, other manifestations and productions of human intellectual achievement. Contemporarily, in the age of genetically modified organisms and nanotechnology, human intervention on any aspect of nature is almost inextricable; while on the other hand, the presence of nature in the structure of any cultural production is incontrovertible. Nevertheless, the concepts of 'nature' and 'culture' - generally positioned as opposing phenomena-have constituted a fluctuant debate throughout history. Although there are still some unresolved cases where the two concepts appear to be contradicting each other, contemporarily, the integration of culture and nature is prioritized in all aspects of heritage studies.

An integral approach towards culture and nature was adopted by UNESCO as the World Heritage committee prepared the initial draft of the Operational Guidelines in 1977. It is stated in the initial draft of the guidelines that: "The cultural and natural heritage are, for each nation and the international community, amongst their most important and priceless possessions" [8]. The initial guidelines have established two sets of criteria (one for cultural property and another for natural property). Until 2005, the two sets of criteria have been utilized; however, in the revised Operational Guidelines in 2005, the evaluation criteria have been integrated to involve all categories (natural sites, cultural sites, and mixed sites) [9].

ICCROM (International Centre for the Study of the Preservation and Restoration of Cultural Property-1956), ICOMOS (International Council on Monuments and Sites-1965) and IUCN (International Union for Conservation of Nature-1948) are the advisory bodies to the World Heritage Committee. 'The International Scientific Committee on Historic Gardens and Sites' of ICOMOS was established in 1971, but a significant change has occurred, shifting the focus on 'gardens' to a broader concept of 'cultural landscapes' as the concept was defined in the 1992 World Heritage Convention, and the name of the committee was changed to 'The International Scientific Committee on Cultural Landscapes ICOMOS-IFLA.' Cultural landscapes are defined as cultural properties representing the 'combined works of nature and of man,' and "they are illustrative of the evolution of human society and settlement over time, under the influence of the physical constraints and/or opportunities presented by their natural environment and of social, economic and cultural forces, both external and internal" [10]. Similarly, the European Landscape Convention of 
2000 defines landscape as "an area, as perceived by people, whose character is the result of the action and interaction of natural and/or human factors" [11].

Considerations on industrial heritage as a component of cultural heritage arose by the end of the 19th century and the theoretical framework was developed in the 20th century. Michael Rix introduced the concept of 'industrial archaeology' in his article in 'Amateur Historian' in 1955 [12]. The International Committee for the Conservation of the Industrial Heritage (TICCIH), established in 1973, published 'The Nizhny Tagil Charter for the Industrial Heritage' in 2003, and defined industrial heritage as: "the remains of industrial culture which are of historical, technological, social, architectural or scientific value. These remains consist of buildings and machinery, workshops, mills and factories, mines and sites for processing and refining, warehouses and stores, places where energy is generated, transmitted and used, transport and all its infrastructure, as well as places used for social activities related to industry such as housing, religious worship or education" [13]. ICOMOS has adopted the Joint ICOMOS-TICCIH Principles for the Conservation of Industrial Heritage Sites, Structures, Areas and Landscapes, also called "The Dublin Principles" in 2011 [14]. Enhancing the Nizhny Tagil Charter, "The Dublin Principles' also includes 'sites' and 'landscapes' in the definition of industrial heritage. The extension in the definition points out the profound connection between cultural and natural environment [4].

Therefore, within the theoretical framework of industrial heritage-based on the Nizhny Tagil Charter of TICCIH [13] and the Dublin Principles [14]—Kuban and Pretelli have specified criteria for the assessment of hydroelectric plants and developed guidelines for interventions. Age/historical value, technological value, architectural/artistic value, integrity, social/economic value, and environmental and/or structural safety are the criteria specified for the assessment of hydroelectric plants in terms of industrial heritage [4].

As is true with all beings, the lifespans of hydroelectric facilities of the past centuries are also limited, and besides the concerns for the conservation of industrial heritage, it is essential to develop strategies for the future of these facilities with regard to safety of life and property. Since they are constructions built against the overwhelming powers of nature, abandoning dams to age within the deteriorative forces of nature constitutes a major risk of disaster. Several examples of hydroelectric plants in Italy that have lost their operational functions have been re-functioned to house new cultural activities. Antonio Pitter Powerhouse (1905) is currently being used as a museum of electricity; the powerhouse of Taccani Hydroelectric Plant (1906), which has partly lost its original function, contemporarily (on certain dates) houses cultural activities such as concerts, exhibitions and educational meetings, and Centrale Fies (1907) was restored and re-functioned as a center for contemporary arts. Re-functioning hydroelectric facilities enables the sustainable maintenance and monitoring of the sites, while providing the transfer of the industrial heritage to the future generations, as cultural tourism routes have started to evolve for the enthusiasts of industrial heritage. 


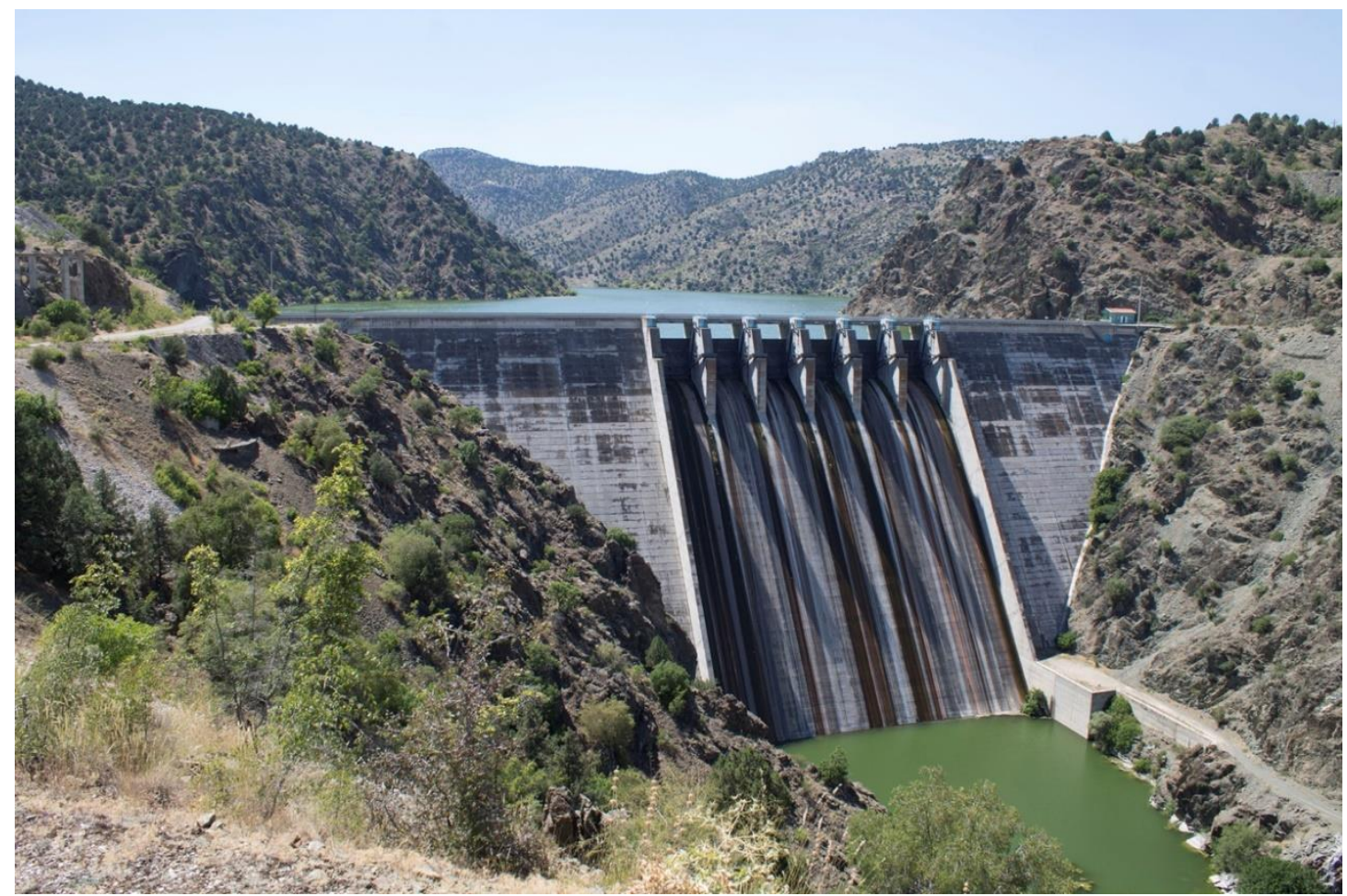

Figure 6. Sariyar Dam-Turkey (photo taken by the author on 14 July 2016).

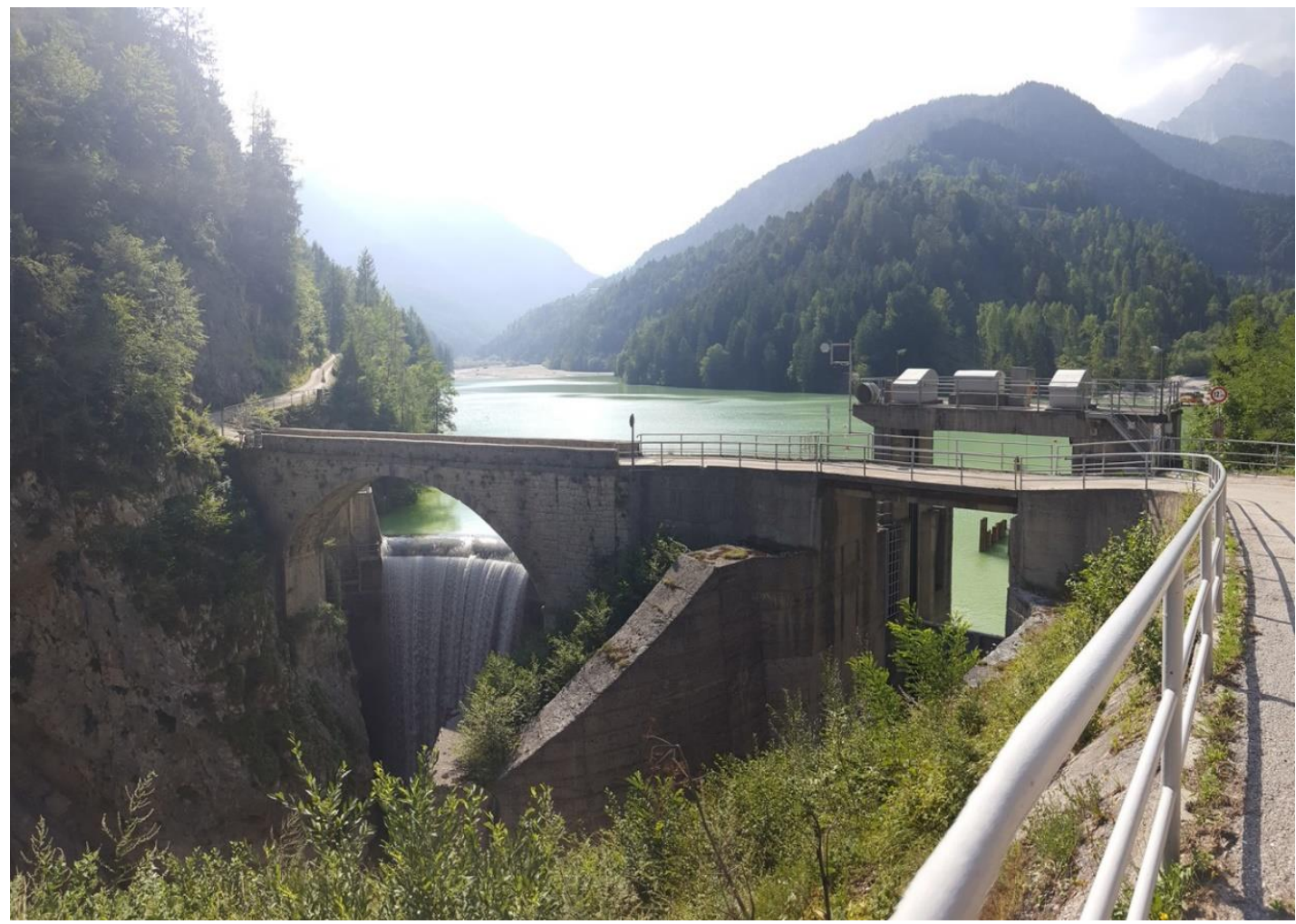

Figure 7. Valle di Cadore Dam-Italy (photo taken by the author on 11 August 2019).

3. Impacts of Hydroelectric Plants and Dams on Assets of Cultural and Natural Heritage

Discussions on the interrelation of nature and culture in urban contexts should not concentrate merely on buildings, but rather they should also include urban substructures 
such as provision of water and energy, collection/removal of waste and sewage, provision of transportation and communication services, establishment of technological infrastructures, and other sub-structural services as indispensable elements of contemporary urban settlements. When such services are provided within the cities, on an already transformed piece of nature, the severity of the interference is sometimes overlooked; however, when hydroelectric facilities, constructed as giant machines on perhaps the most charming natural terrains - on cascading rivers and narrow valleys-are concerned, the relationship between nature and human intervention appears as a greater contrast. 'Damnation' of dams is a result of their effects on natural and cultural properties.

Public works of urban substructures, such as the construction of hydroelectric facilities, are not unexpected disasters; therefore, prior to such interventions, the entire territory has to be scanned in order to document all natural and cultural properties; severity and characteristics of possible impacts of the construction have to be specified in advance. After consultations and negotiations, only in cases of indispensable requirements, a compromise is foreseen. All traces of human interventions throughout history are within the scope of archaeological heritage, and there is almost no piece of land untouched by human beings. In this context, according to the conservation approach developed after the 1960s, entrepreneurs of such radical public works have been obliged to document the cultural heritage in the territory [15]. Therefore, archaeological documentation and excavation work is also carried out as part of such projects. However, either foreseen by the investors and constructors or not, due to inadequacies in the specification of their sites, hydroelectric plants - in many cases - have affected indigenous settlements, urban or rural sites, and other cultural properties. Construction of large dams has evidently resulted in catastrophes of flooding, removal, or abandoning of cultural heritage sites through the displacement of inhabitants in various parts of the world, such as Abu Simbel Temples (Egypt), Hasankeyf (Turkey), and The Three Gorges Dam (China).

In ecological and environmental aspects, hydroelectric plants constitute a major source of renewable energy, and they also contribute to mitigating the effects of water crisis and achieving sustainability goals by preventing the flooding of land and providing water for irrigation and usage. However, hydroelectric facilities are accused of the drastic transformations they cause in the physical, climatic, and ecological conditions of the aquatic and terrestrial ecosystems they are located in. Major impacts of dams on natural properties are the habitat alteration of rivers, loss of floodplains and wetlands, deterioration and loss of river deltas, and dewatering of rivers [16]. Disturbance of river flows may be regulated through contemporary methods of ecological flow [17]. Environmental concerns also include dams blocking fish runs causing the extinction of species in some cases. Methods such as fish ladders and other passage facilities have been developed, but in many cases, they are considered to be too expensive to implement. Therefore, there are many contemporary attempts to remove dams, especially in the USA, in order to provide the free flow of rivers.

At this point, it is important to re-emphasize that this study does not intend to discuss the construction of new hydroelectric facilities but rather analyzes the cases of hydroelectric plants constructed in the past century. Thus, it should be noted that the ecological conditions in the terrains discussed have already been altered approximately a century ago. Therefore, the question intended to be raised within the discussion is whether removing an existing dam would create a positive effect on the natural environment or whether such an intervention would disturb a new equilibrium that nature has constituted within the 100 after the initial human intervention. Currently, the answer to this question remains indefinite, since not enough time has passed after the experienced cases of dam removals. Bellmore et al. have developed conceptual ecological response models for dam removals, and they have concluded that "rivers, given the opportunity, can indeed recover substantially from having been dammed, but the structure and function of the ecosystem may not be the same or even similar to what existed prior to dam emplacement," and they emphasize that "the ability to go back to a pre-dammed state will likely depend on how 
long the dam existed and the magnitude of its many-faceted effects on the ecosystem." [18]. Therefore, even after the removal of hydroelectric plants, it appears unlikely to restore the 'virginity' of the landscape -as nature in its purest form.

\section{Impacts of Nature on Hydroelectric Plants and Dams}

Negative effects of dams and hydroelectric plants on nature have been extensively discussed in numerous studies [18-22]. In this study, with a twist of cons and pros, the impacts of nature on these facilities are also examined with an aim to highlight the risks on the hydroelectric facilities of industrial heritage.

\subsection{Natural Disasters and Accidents Causing Dam Failures}

In order to make life easier for himself, throughout history, humankind has struggled to control, transform, and re-design nature in line with his own needs. One of the most explicit examples of this struggle is the case of dams constructed against the flow of rivers for the aim of obtaining energy. These structures, which were built against the forces of nature by pushing the limits of human intelligence and engineering knowledge, have succumbed to nature in some cases. In such circumstances, as is true in all kinds of natural disasters, nature maintains its own cycle under the new conditions established by the intervention; what makes this process a disaster are the humans' inadequate decisions, lack of technological experience, and inability to manage the process.

Natural causes such as seismic events, the change in flow rates, unusual weather conditions, and material degradation have resulted in dam failures when combined with human errors such as inadequate foundations, poor construction quality, and operational mishaps [23]. Seismic events have been responsible for several dam failures; while on the other hand, in some cases, the seismicity of an entire region has been increased due to hydrostatic pressures induced by large reservoirs [23].

Gleno Dam, constructed in 1916-1923 in Italy, was defeated by the power of nature and collapsed on 1 December 1923. The disaster caused several villages to be flooded and killed at least 356 people [24]. Although Gleno Dam was originally designed as a gravity dam, after the construction of the foundation, the body of the dam was completed as a multiple-arch structure. The two different types of dams require distinct methods and calculations of their foundations; therefore, building a multiple-arch dam over the foundation of a gravity dam was an engineering mistake [25]. In addition, usage of lowstandard materials and workmanship was reported during the construction process [26]. Thus, Gleno Dam could not withstand the pressure of nature, and failed due to mishaps in the design and use of inadequate materials and techniques. Some sections of the dam still remain at the site, and 'Gleno Exhibition Space' is established to present a collection of documents and photographs, commemorating the disaster, and describing the dam as a witness of the industrial heritage in the 1920s (Figure 8).
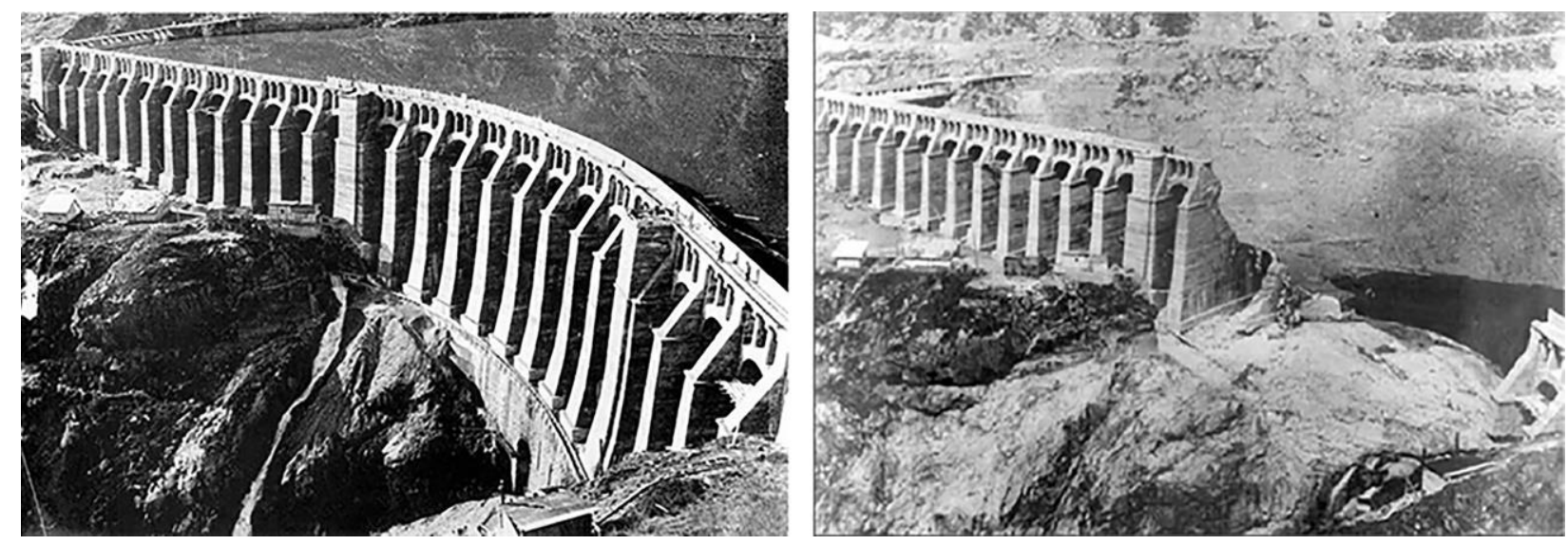

Figure 8. Gleno Dam before and after the failure [26]. 
Vajont Dam was constructed between 1956 and 1961 on Piave River (Italy). Throughout years of operation, landslides were frequently occurring around the basin of the dam, and operators at the facilities were lowering the level of the reservoir accordingly in order to prevent the overtopping of water. However, on 9 October 1963, three years after the initial filling of the basin, with a huge, sudden landslide, the land surrounding the basin fell into the reservoir causing massive amount of water to overtop the dam, destroyed settlements, and caused about 2000 causalities [27]. It is reported that the reservoir, created by the dam, had caused the loosening of land around the basin -increasing the impact of the landslide [28]. The case proves that, even after the completion of construction works, careful monitoring of any changes in the surrounding environment is required for dam safety. Vajont Dam is an extraordinary case of dam failure, because-regardless of the huge amount of water overtopping it - the dam did not collapse; it still remains intact at the site. Currently, the river is diverted from the dam and the reservoir does not exist anymore. The dam is open to public, and a visitors' center is created for the memory of the disaster.

Upriver Hydroelectric Plant was built on Spokane River in the USA in 1936, and modifications were made in 1984. On 20 May 1986, lightning struck an interconnection electrical line, shutting the turbines and generators down. Backup power systems failed; spillway gates could not be opened, and water rose behind the dam, overtopping it and causing damage to the facilities. A section of the parapet wall was damaged; substantial erosion occurred in the canal bank; the powerhouse was undermined, displaced, and tilted on its foundations [23]. The reasons of the accident have been defined as deficiencies in reservoir freeboard, electrical systems, mechanical systems, emergency action plan, operator training and staffing, equipment maintenance, management and budgeting procedures, and regulatory agencies' review [29]. No deaths or significant damage-other than to the facility itself-was reported for this incident. This example is introduced not because of its tragic results, but simply to emphasize the multiple weaknesses that can be uncovered in a particular chain of events.

\subsection{Deterioration of Dams due to Natural Aging}

Beyond sudden and exceptional circumstances-such as floods, upstream dam break waves, earthquakes, and war-dam failures may also occur as a result of natural aging of the facility [30]. In Turkey, the economic life of a dam is considered to be approximately 50 years, and specific calculation methods are used for the estimation of the service life of each plant [31]. Information about the hydroelectric plants (with the installed capacity over 50 MW) constructed before 1975 in Turkey is presented in Table 2 and Figure 9. In USA, the service period of a dam is defined to be 100 years; however, the Federal Energy Regulatory Commission (FERC) of the USA requires the renewal of the operation license of each hydroelectric plant in 30-50 years. ICOLD (International Commission on Large Dams) has been organizing congresses since 1933 where dam safety and deterioration of dams are discussed in a wide spectrum of issues [32]. During a panel on dam ageing at ICOLD's 1991 Congress, it was mentioned that "in the future, attention and activity [will] be more and more shifted from the design and construction of new dams to the restoration of the structural and operational safety of existing dams" [33].

Material degradation is among the main results of natural aging. In case of concrete dams, water is usually involved as a deteriorative factor, and the severity of the degradation is directly related to the degree of permeability. Other physical impacts on the durability of concrete include: Surface weathering, cracks due to presence of salts, and temperature extremities such as fire or frost. Chemical effects deteriorating concrete include: Acidic solutions leaching the cement paste, sulphate attack, alkali-aggregate reactions, and corrosion of embedded steel [34]. 
Table 2. Documentation of hydroelectric plants (with the installed capacity over $50 \mathrm{MW}$ ) constructed before 1975 in Turkey.

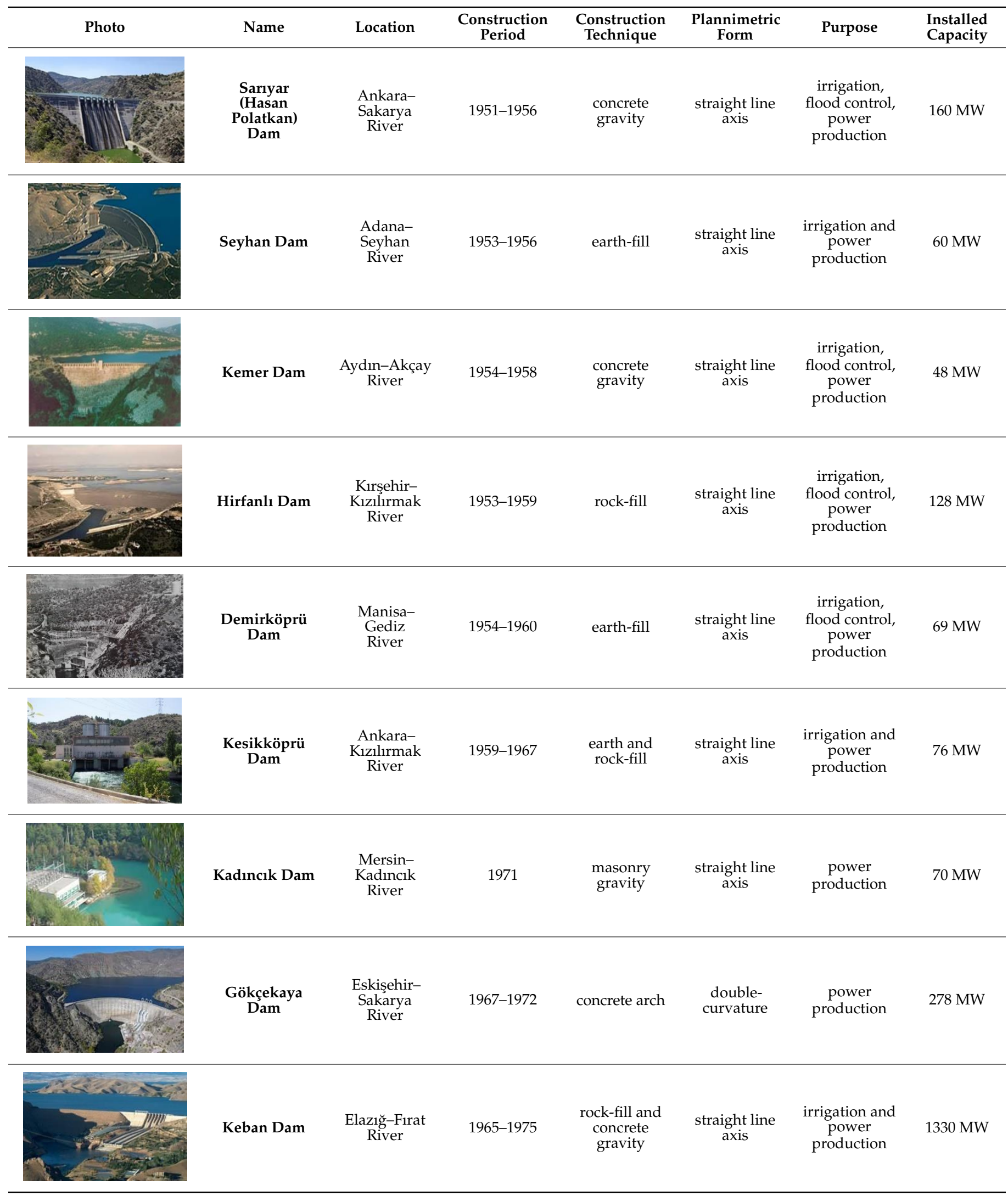




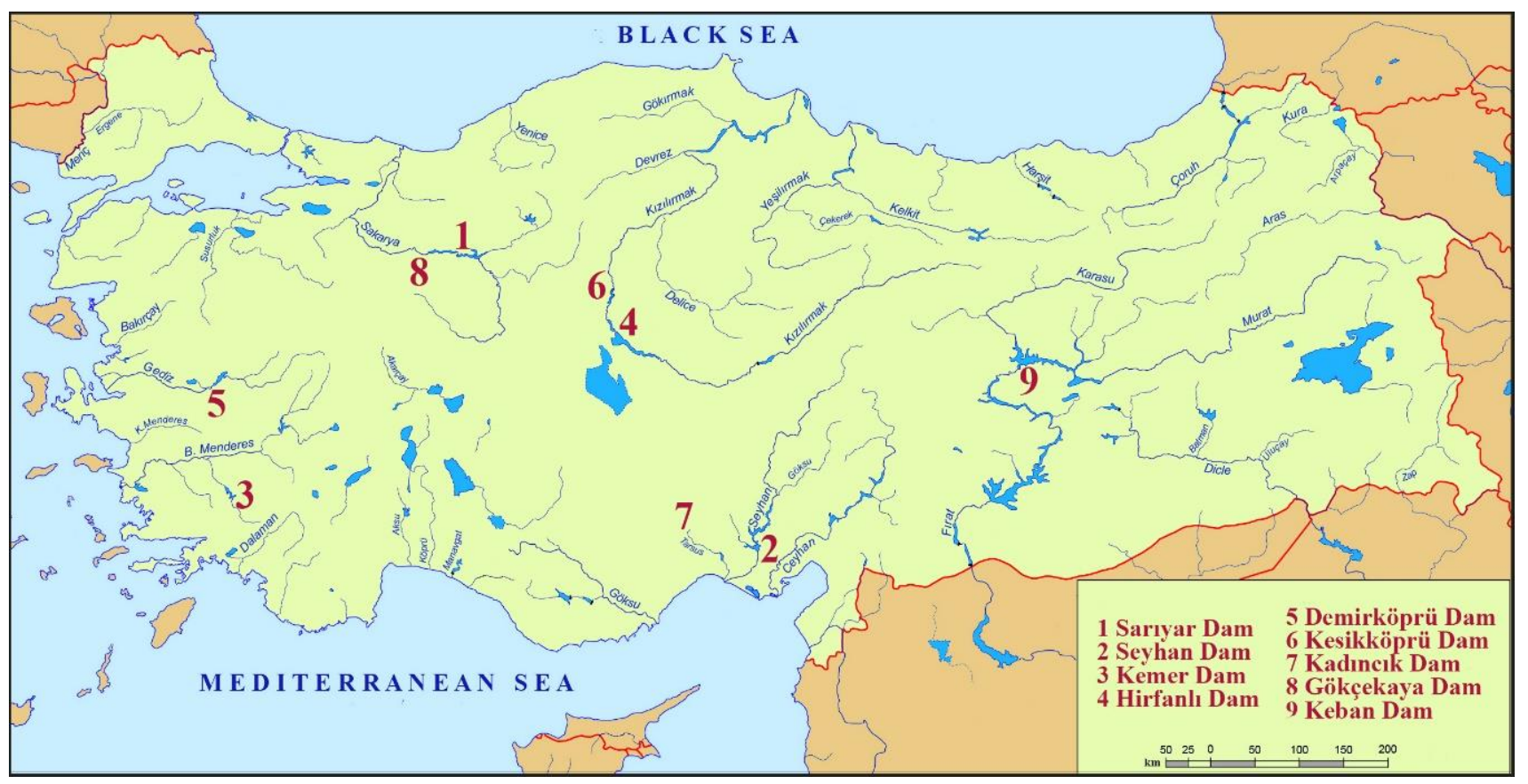

Figure 9. Map of hydroelectric plants (with the installed capacity over $50 \mathrm{MW}$ ) constructed before 1975 in Turkey.

Structural stability of dams is an important issue for dam safety. FERC categorizes loads acting on dams as: Dead loads, external water-imposed loads, internal loads, earth and silt pressures, earthquake forces, and ice loads [35]. Methods for the stability analysis of dams are defined as: Gravity method, finite element methods, dynamic methods and cracked base analysis [28].

Material degradations and structural weaknesses are fundamental problems that have to be encountered during the design and construction of a dam. However, beyond the initial phases of establishment, throughout all years of operation, it is required to keep up with dam safety measures by careful analysis, maintenance and monitoring of the embankment, the reservoir, the powerhouse, and the machinery installed. Moreover, a periodic and thorough inspection of the geology and topography of the surrounding landscape-focusing on changes in climatic and environmental conditions-is also essential for dam safety.

Deformation or displacement of dams may constitute an essential indication of a possible disaster and even small magnitudes of such activities can be inspected through metrological monitoring methods, photogrammetric techniques, and terrestrial laser scanning [28]. The accumulation of sediment in reservoirs causes severe consequences in water management, flood control, and energy production. Measures can be taken for the reduction of incoming sediment such as trapping the sediment upstream or providing vegetation filters. Flushing is an effective method for the removal of sediment, but it is required to consider possible negative impacts on downstream river ecosystem in order to develop an appropriate flushing strategy [36]. Detailed analysis of the landscape is an important component of dam safety. Numerical models are being utilized to understand morphological changes in rivers and floodplains, along with the hydrologic and geomorphological conditions of catchments [37].

\subsection{Intentional Removal of Dams due to Ecological Concerns}

As discussed earlier, since hydroelectric plants affect the flow of rivers and change the ecosystem, removal of dams has become an important concern for the restoration of the natural environment. Removal of dams is perceived as a tool for waterfront revitalization, improvement of water quality, and the natural movement of sediment and other nutrients through the re-establishment of natural flow regime [20]. 
For the removal of a dam, it is essential to consider the short-term and long-term impacts of the intervention. Bellmore et al. emphasize that it is difficult to precisely define the temporality of the 'short' and 'long' term impacts, because events may occur relatively fast for some removals but slower for others. They categorize short-term impacts as the responses initiated directly by the removal (such as sediment release and its direct impact on the habitat); whereas long-term impacts are associated with natural responses towards building a new dynamic equilibrium (such as the reestablishment of organisms) [18].

Bellmore et al. report that the ecological communities assembled within the long-term response after the removal of a dam may be entirely different from those that existed before, and the conditions of the watershed may have changed significantly during the lifespan of the dam [18]. Therefore, it is important to consider that the removal may also constitute a second major intervention in nature by interrupting the equilibrium settled in the long presence of the dam. Moreover, preventive measures are required for mitigating risks of flooding and landslides during or after the removal, in order to preserve urban/rural settlements and cultural assets in the vicinity of the dam.

Factors effecting the decisions on dam removals are: Size, environmental impact, age, and productivity of the facility. Smaller dams, with high negative impacts on the environment, the productivity of which have decreased due to aging, are more likely to be removed. Two of the largest hydro-electric dams removed are Elwha Dam and Condit Dam in the USA. Both Condit Dam (1913) and Elwha Dam (1914) had been registered in the US National Register of Historical Places as elements of industrial heritage [38]. However due to ecological concerns, Condit Dam was removed between October-September 2012, and Elwha Dam was demolished between September 2011 and March 2012 [2,28]. Prior to removal of both facilities, reports have been prepared regarding the impacts on cultural properties and resources. Elwha Dam was demolished with all its components, whereas the powerhouse of Condit Dam currently remains abandoned at the site with expectations of an adaptive re-use. Allen et al. report that within the removal of Condit Dam, the reservoir erosion was faster and effective further upstream than expected, and $24 \%$ of the salmon fish nests were eroded [39]. However, it is also important to consider that it takes time for nature to regain equilibrium, and long-term results of the removal are yet to be experienced (Figure 10).

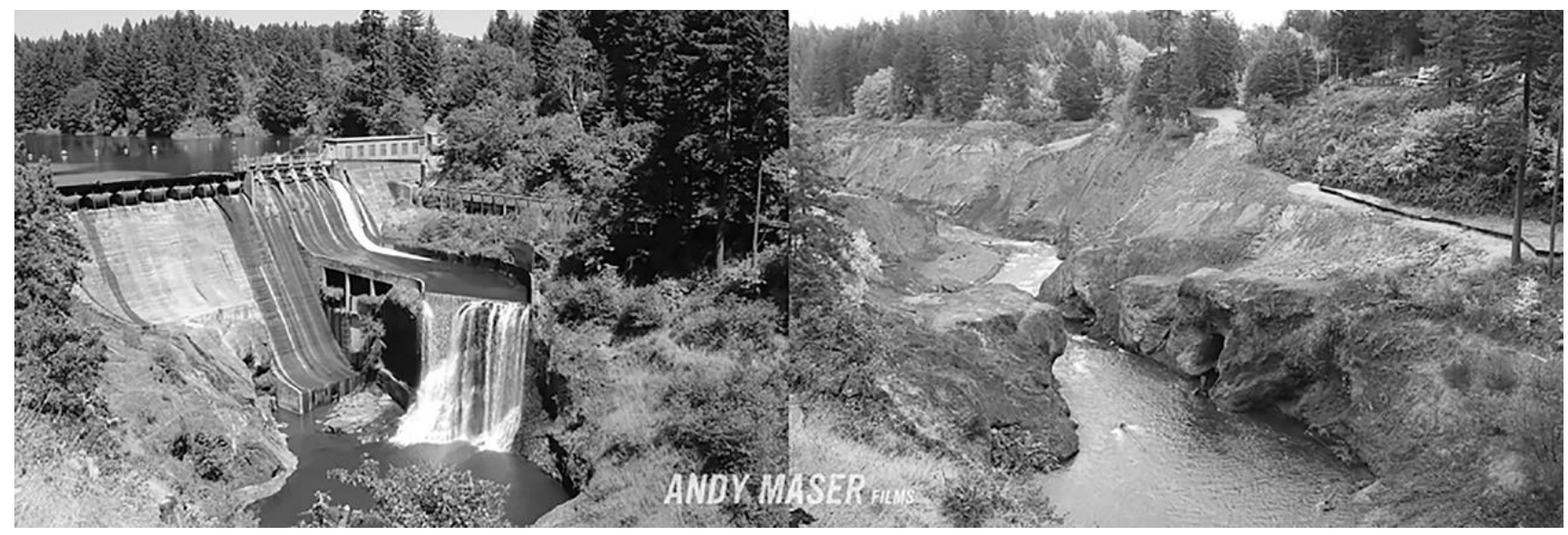

Figure 10. Condit Dam before and after the removal [40].

\section{Discussion}

Based on the research results, a flowchart throughout the lifespan of hydroelectric plants - starting with their design phase and concluding with the end of their operational efficiency - which depicts their interactions with their cultural and natural environments, including opportunities, threats, and measures for the mitigation of threats is schematized in Figure 11. The flowchart suggests measures to mitigate possible threats on their envi- 
ronments throughout the entire presence of these energy facilities and reveals the possible approaches regarding the end of their operational efficiencies.

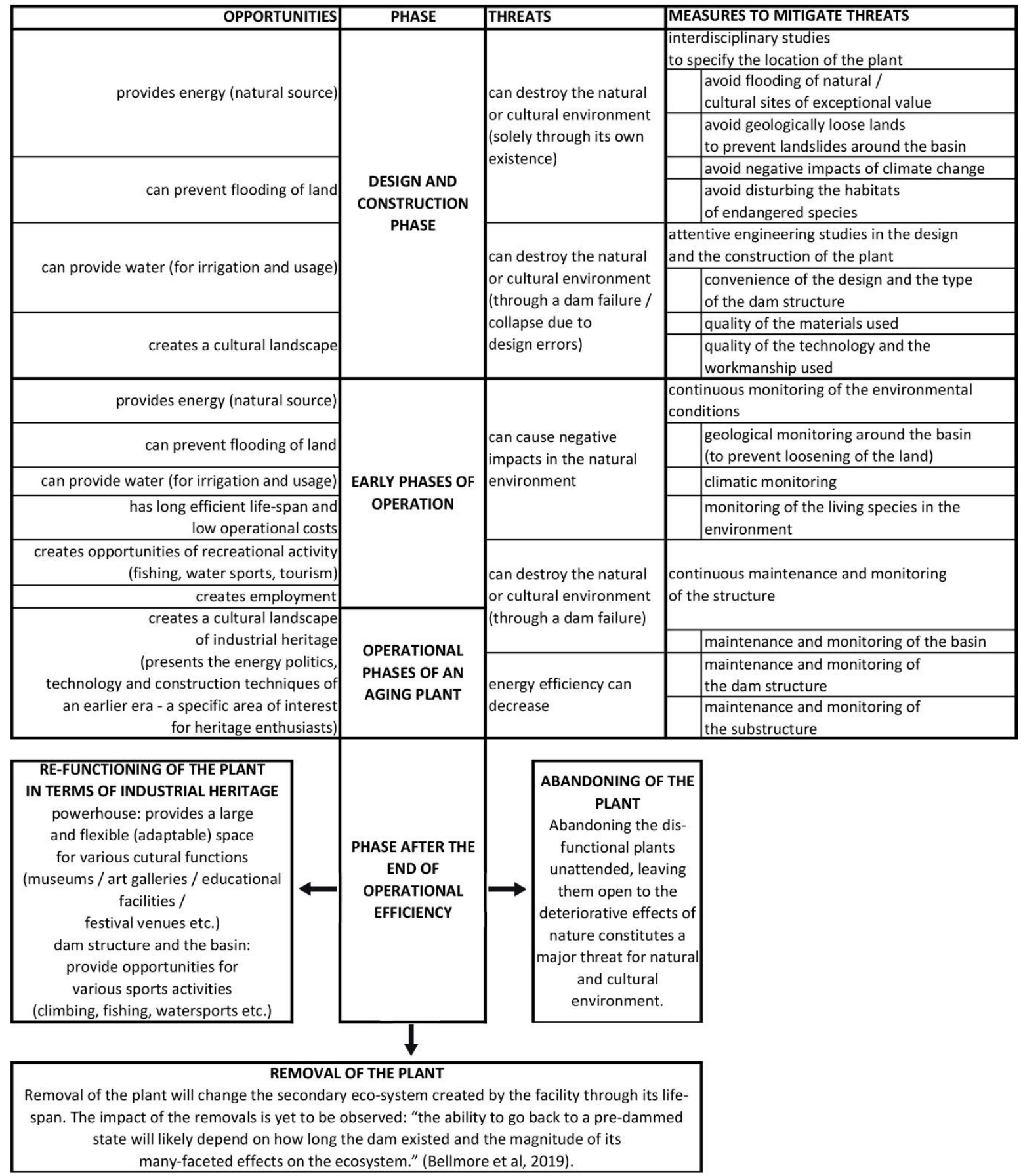

Figure 11. Flowchart throughout the lifespan of hydroelectric plants their interactions with cultural and natural environments, including opportunities, threats, and measures for the mitigation of threats.

Hydroelectric plants constitute a major source of renewable energy for their surroundings, and depending on the initial aim, they also have the potentiality to contribute to achieving sustainability goals by preventing the flooding of land and providing water for irrigation and usage. In any case, they create a cultural landscape representing the combined works of nature and of humankind. Within hydroelectric plants, the forces of nature are integrated with the technological intervention of human intelligence to reveal the associated historical evolution of humankind in nature. However, as explained in 
the study, hydroelectric plants may also create threats of destroying their natural and cultural environments solely through their existence or through dam failures. It is important to emphasize that such threats occur in cases of humans' inadequate decisions, lack of technological experience, and inabilities to manage the process. Therefore, in order to prevent the destruction of the environment, interdisciplinary studies need to be conducted to specify the location of the plant, and attentive engineering studies need to be carried out in the design and construction phases. Specifying the location of the plant requires a conscientious approach to avoid:

- The flooding of natural and cultural sites of importance,

- Geologically loose lands to prevent landslides around the basin,

- Negative impacts of climate change,

- Disturbing the habitats of endangered species.

Mishaps in the design and construction phases may also create threats of dam failures and destruction of the surrounding environment. In order to prevent such cases attentive engineering works are required such as:

- Design of the convenient dam-type in accordance with the contextual requirements,

- Quality of the construction materials,

- Quality of the technology and the workmanship.

Beginning with the early phases of operation, dam may cause negative impacts on the natural environment; therefore, a continuous monitoring of the environmental conditions is required, including the geological monitoring around the basin (to prevent loosening of the land), climatic monitoring, and monitoring of the living species in the environment.

Active measures may sometimes be required to mitigate the deteriorative effects of dams on their natural environments. Flow variability is a major driver of the healthy river ecosystem, whereby discharging a certain amount of water could potentially reduce the adverse effect of reservoirs and dams on the riverine ecosystem [41]. Studies reveal that usage of environmental flow methods promotes hydropower production while contributing to the protection of habitats [42]. Blockage of fish migration routes is one of the negative impacts of hydroelectric plants on natural environments. The most effective means to develop successful installations of fish-passages to prevent blocking of fish migration occurs when engineers and biologists work together systematically to develop effective passage systems and to try creative solutions using natural materials [43].

With the aging of the dam structure, other threats appear such as: Dam failures due to aging and decrease in energy efficiency. Continuous maintenance and monitoring of the facilities are essential in order to prevent such risks. Maintenance and monitoring of the basin, the dam structure, and the substructure are required along with the technological equipment of the hydroelectric facilities.

In order to discuss the aging of hydroelectric plants, a study has been carried out to analyze hydroelectric plants constructed in Turkey and Italy in the 20th century. Since the construction of such facilities usually lasts several years, the inauguration dates are used in the dating of plants, and the year 1975 was determined as the end date of the review, due to the soundness of the data to be compared in the two countries and to define an approximate time frame for industrial heritage. Evaluation of the inventories reveals that: In Turkey, dams constructed before 1950 were built for other purposes such as flood mitigation, irrigation, and water supply, and hydroelectricity was developed in the second half of the century. Documenting the plants introduced in the publications by ANIDEL and ENEL, it is observed that in Italy, 164 hydroelectric plants had already been constructed before 1950 [5,44]. In the third quarter of the century (1950-1975), 68 hydroelectric plants were constructed in Turkey, and 98 hydroelectric plants were built in Italy. Out of the 68 hydroelectric plants built in Turkey by 1975, 10 facilities have installed capacities larger than 50 MW (Table 2 and Figure 9). Considering the hydroelectric plants in both countries, it is observed that the number of aging plants will soon be a significant issue of concern. 
It will be essential to develop a methodology and an approach to deal with these huge engineering structures after the end of their active functions.

The study on the examples in Turkey and Italy was further developed to present the current statuses of the facilities. An overview of the examples revealed that most of the plants built after 1950 in both countries are still active in producing electricity; however, in Italy, some of the hydroelectric plants constructed in the first half of the century have lost their initial functions. In order to observe and evaluate their current statuses, site visits were made to hydroelectric facilities of Antonio Pitter (1905), Taccani (1906) and Centrale Fies (1907). Antonio Pitter Hydroelectric Plant was dismissed in 1988, and the powerhouse was re-functioned as a museum of hydroelectricity in 2006. Taccani of Trezzo had been initially designed as a combined facility of hydro and thermo electric plant; however, the thermoelectric function has ended, and the hall of thermoelectricity is currently being used for cultural purposes. Centrale Fies was dismissed in 1961, and after long years of abandonment, by the beginning of the 21st century, the powerhouse was re-functioned as a place permanently dedicated to contemporary arts. Site visits were also made to other facilities such as: Bissina Dam, which is still in use with an additional function (sportive activity—speed rock climbing); Vajont Dam, which is a dismissed-failed dam being used as a place of memory; Cellina Dam, which is a dismissed-abandoned dam; Pieve di Cadore Dam, which is an active dam with an additional sportive function of climbing at seasonal periods.

As tools for a sustainable habitat and colossal examples of industrial heritage, it is necessary to make every effort to ensure that hydroelectric plants maintain their productive lives as long as possible. As instruments of clean energy, hydroelectric plants have long efficient lifespans with low operational costs. However, as is true with all beings, lifespans of hydroelectric facilities are also limited. Within the phase at the end of the operational efficiency, a decision needs to be made between abandoning, re-functioning, or removing the facility.

After the end of its efficient lifespan, abandoning a hydroelectric power plant, neglected and unmonitored against the destructive forces of nature, poses a major threat to the structure itself and its natural and cultural environment. On the other hand, as mentioned above, the economic, practical, and ecological benefits and challenges of dam dismantling and removal are still debated. Therefore, re-functioning seems to be a favorable option for hydroelectric power plants that have completed their functional lives. Introduction of the new function will ensure the continuity of maintenance and monitoring while allowing the cultural property to be transferred to future generations as a component of industrial heritage.

\section{Conclusions}

Within the discussion on culture-nature duality, it shall not be forgotten that-either with or without the presence of architects or engineers-all activities of construction are basically transformations of nature as they intervene to the surface of the solid earth. Therefore, to a larger extent, culture can be interpreted as the regeneration of nature through human activity, as both Hegel and Bookchin define 'culture' as 'second nature.' Through each construction, the border between the solid — which we stand on - and the gas - which we cannot grasp - is being changed; an extension of the solid-earth is being established in accordance with human needs. In this study, besides the solid-earth and air, 'water' is also addressed as one of the interfaces of the earth, and the domination of humankind on water is examined, through the example of hydroelectric plants-'the giant machines buried into the body of the earth.'

Dams are tools for generating energy, and like all tools, they have a limited period of efficient life. When costs required to sustain efficiency and to mitigate natural and safety hazards outweigh the benefits of dams, options of decommissioning and removal start being considered. It is reported that a dramatic rise in the operational costs is experienced after around 25-35 years of hydroelectric production, and it is also emphasized that removal 
of a dam could cost more than building one [33]. Decommissioning by disconnecting the dam from the energy grid and ceasing power production is a possible method to avoid operational costs; however, abandoning the dams, which have completed their efficient lives, open to deteriorative effects of nature constitutes a major threat for future generations.

Moreover, hydroelectric plants and dams of the past century are a component of industrial heritage, and conservation of such facilities is a cultural requirement since they are the evidence of the energy politics and construction/production technologies of a certain period in history. Therefore, through the consideration of their levels of productivity, age/historical values, technological values, architectural/artistic values, status of integrity, social/economic values, and conditions of environmental and structural safety, an evaluation should be made regarding the specification of the facilities to be conserved for future generations. Interdisciplinary studies should be conducted with the collaborations of experts on issues of ecology, engineering, social sciences, and heritage conservation in order to decide on whether the removal of a certain dam could adversely affect the natural and cultural environment, and methods should be specified for avoiding, minimizing, and mitigating such negative impacts $[16,18,20,22,45,46]$. Possibilities of adaptive re-use, maintenance, and preventive measures should be prioritized for the conservation of hydroelectric facilities of cultural heritage, and appropriate contemporary technologies should be implemented for the removal of discarded facilities.

Funding: The research, on which this article is based, was funded by the Scientific and Technological Research Council of Turkey (TÜBİTAK) under Grant 2219 (International Postdoctoral Research Fellowship Programme).

Acknowledgments: Amajor part of this research was conducted (October 2018-October 2019) at the Department of Architecture (Alma Mater Studiorum-Bologna University) under the supervision of Marco Pretelli.

Conflicts of Interest: The author declares no conflict of interest. The funders had no role in the design of the study; in the collection, analyses, or interpretation of data; in the writing of the manuscript, or in the decision to publish the results.

\section{References}

1. Bookchin, M. Özgürlü̆̆̈̈n Ekolojisi: Hiyerarşinin Ortaya Çıkışı ve Çözülü̈şü [The Ecology of Freedom: The Emergence and Dissolution of Hierarchy]; Coşkun, M.K., Translator; Sümer Yayıncılık: İstanbul, Turkey, 2013; p. 308. (In Turkish)

2. Kuban, N. Hydroelectric Power Plants as a Subject in the Re-Use of Industrial Heritage. In Il Patrimonio Culturale in Mutamento: Le Sfide dell'Uso [Changing Cultural Heritage: The Challenges of Use]; Ricerche, A., Ed.; Scienza e Beni Culturali: Bressanone, Italy, 2019; pp. 1027-1036.

3. Ural, O.M.; Ünver, U. Large Dams in Turkey; DSİ: Ankara, Turkey, 1967; p. 82.

4. Kuban, N.; Pretelli, M. Industrial Heritage Assessment and Guidelines for the Architectural Conservation of Hydroelectric Plants. Int. J. Archit. Herit. 2019, 1-21. [CrossRef]

5. Anidel (Associazione Nazionale Imprese Produttrici e Distributrici di Energia Elettrica/National Association of Producers and Distributors of Electricity). Le Dighe di Ritenuta degli Impianti Idroelettrici Italiani [The Dams of Italian Hydroelectric Plants]; ANIDEL: Rome, Italy, 1961; Volume 4, p. 79. (In Italian)

6. Menini, G. L'Architetture del 'Carbone Bianco' [The Architecture of the 'White Coal']. In I luoghi dell'acqua: Architetture e paessagi delle centrali elettriche in Valtellina [The Places of Water: Architecture and Landscape of Hydroelectric Plants in Valtellina]; Menini, G., Ed.; Credito Valtellinese: Sondrio, Italy, 2013. (In Italian)

7. Bossum, E. Valorisation et Interprétation du Patrimoine Hydroélectrique dans le Paysage Contemporain en Italie [Valorization and Interpretation of the Hydroelectric Heritage in the Contemporary Landscape in Italy]. e-Phaistos 2015, IV, 60-70. (In French) [CrossRef]

8. Operational Guidelines for the World Heritage Committee/UNESCO World Heritage Committee. 1977. Available online: https:/ / whc.unesco.org/archive/opguide77a.pdf (accessed on 13 February 2021).

9. Operational Guidelines for the Implementation of the World Heritage Convention/UNESCO World Heritage Centre. 2005. Available online: https://whc.unesco.org/archive/opguide05-en.pdf (accessed on 13 February 2021).

10. Operational Guidelines for the Implementation of the World Heritage Convention/UNESCO World Heritage Centre. 2019. Available online: https:/ / whc.unesco.org/en/guidelines (accessed on 13 February 2021).

11. European Landscape Convention/Council of Europe. 2000. Available online: https://rm.coe.int/1680080621 (accessed on 13 February 2021). 
12. Rix, M. Industrial Archaeology. Amat. Hist. 1955, 2, 225-229.

13. The Nizhny Tagil Charter for the Industrial Heritage. 2003. Available online: https://www.icomos.org/18thapril/2006/nizhnytagil-charter-e.pdf (accessed on 23 December 2020).

14. Joint ICOMOS-TICCIH Principles for the Conservation of Industrial Heritage Sites, Structures, Areas and Landscapes: The Dublin Principles. 2011. Available online: https://ticcih.org/wp-content/uploads/2013/10/GA2011_ICOMOS_TICCIH_joint_ principles_EN_FR_final_20120110.pdf (accessed on 23 December 2020).

15. Tarih Vakfı. Zeugma Yalnız Değil! Türkiye'de Barajlar ve Kültürel Miras [Zeugma is not Alone! Dams and Cultural Heritage in Turkey]; Türkiye Ekonomik ve Toplumsal Tarih Vakfı: İstanbul, Turkey, 2000; p. 13. (In Turkish)

16. Tullos, D.D.; Collins, M.J.; Bellmore, J.R.; Bountry, J.A.; Connolly, P.J.; Shafroth, P.B.; Wilcox, A.C. Synthesis of Common Management Concerns Associated with Dam Removal. J. Am. Water Resour. Assoc. 2016, 52, 1179-1206. [CrossRef]

17. Suwal, N.; Kuriqi, A.; Huang, X.; Delgado, J.; Mlnski, D.; Walega, A. Environmental Flows Assessment in Nepal: The Case of Kaligandaki River. Sustainability 2020, 12, 8766. [CrossRef]

18. Bellmore, J.R.; Pess, G.R.; Duda, J.J.; O’Connor, J.E.; East, A.E.; Folley, M.M.; Wilcox, A.C. Conceptualizing Ecological Responses to Dam Removal: If You Remove It, What's to Come? BioScience 2019, 69, 26-39. [CrossRef] [PubMed]

19. Berga, L.; Buil, J.M.; Bofill, E.; De Cea, J.C.; Garcia Perez, J.A.; Mañueco, G.; Polimon, J.; Soriano, A.; Yagüe, J. Dams and Reservoirs, Societies and Environment in the 21st Century; CRC Press: New York, NY, USA, 2006.

20. McClain, S.; Lindloff, S.; Baer, K. Dam Removal and Historic Preservation/Reconciling Dual Objectives. Provided by American Rivers. Available online: https:/ / www.americanrivers.org/conservation-resource/dam-removal-historic-preservationreconciling-dual-objective/ (accessed on 23 December 2020).

21. Magilligan, F.J.; Graber, B.E.; Nislow, K.H.; Chipman, J.W.; Sneddon, C.S.; Fox, C.A. River Restoration by Dam Removal: Enhancing Connectivity at Watershed Scales. Elem. Sci. Anthr. 2016, 4, 1-14. [CrossRef]

22. Fox, C.A.; Magilligan, F.J.; Sneddon, C.S. You Kill the Dam, You are Killing a Part of Me: Dam Removal and the Environmental Politics of River Restoration. Geoforum 2016, 70, 93-104. [CrossRef]

23. Feld, J.; Carper, K.L. Construction Failure; Wiley Interscience Publication: New York, NY, USA, 1997.

24. Petrucci, G. Il Disastro del Gleno, il 'Piccolo Vajont' Dimenticato [The Gleno Disaster, the Forgotten 'Little Vajont']. (In Italian). Provided by: Redazione MeteoWeb. 13 July. Available online: http:/ / www.scalve.it/gleno/Pubblicazioni/GlenoPetrucci.pdf (accessed on 23 December 2020).

25. Barbisan, U. Il Crollo della Diga di Pian del Gleno: Errore Tecnico? [The collapse of the Gleno Dam: Technical Error?]; Tecnologos, Lezioni dalla Storia: Cavriana, Italy, 2007. (In Italian)

26. Luino, F.; Tosatti, G.; Bonaria, V. Dam Failures in the 20th Century: Nearly 1000 Avoidable Victims in Italy Alone. J. Environ. Sci. Eng. 2014, 3, 19-31.

27. Hardenberg, W.G. Expecting Disaster: The 1963 Landslide of the Vajont Dam. Environ. Soc. Portal Arcadia 2011. [CrossRef]

28. Kuban, N.; Güven, I.T.; Pretelli, M. Management of 20th Century Hydroelectric Plants as Industrial Heritage. Int. Arch. Photogramm. Remote Sens. Spat. Inf. Sci. 2019, 5, 685-692. [CrossRef]

29. Hokenson, R.A.; Shelton, W.L.; Verigin, W.M.; Miller, G.W.; Nandagopal, M.R. Upriver Dam Hydroelectric Project Rehabilitation After Failure, Part A: Failure Investigation and Lessons to be Learned. In Water Power '87; Clowes, B.W., Ed.; American Society of Civil Engineers: New York, NY, USA, 1988.

30. Slunga, E. Concept and Bases of Risk Analysis for Dams/With an Example Application on Kyrkösjärvi Dam. 2001. Provided by RESCDAM-Project. Available online: https:/ / pdfs.semanticscholar.org/39a5/6872f901f7eba3951cde1a9a929cbef00822.pdf? _ga=2.117451465.1744748394.1584468942-1572894739.1573547698 (accessed on 23 December 2020).

31. Aydemir, H.; Aşk, K. Sarıyar Hidroelektrik Barajı Rezervuarına Taşınan Rüsubat Miktarının Tesbiti Konusunda Yapılan Bir Araştırma ve Bazı Teklifler [A Research and Some Suggestions on the Determination of the Amount of Sediment Carried to the Sartyar Hydroelectric Dam Reservoir]; Ormancılık Araştırma Enstitüsü Yayını: Ankara, Turkey, 1967. (In Turkish)

32. ICOLD. Twenty-sixth International Congress on Large Dams; CRC Press: New York, NY, USA, 2018.

33. McCully, P. Getting Old: Dam Aging and Decommissioning. In Silenced Rivers: The Ecology and Politics of Large Dams; Zed Books: London, UK, 1996.

34. Charlwood, R.G. Predicting the Long Term Behaviour and Service Life of Concrete Dams. In LTBD09: Proceedings of the 2nd International Conference on Long Term Behaviour of Dams 12-13 October 2009, Graz, Austria; Bauer, E., Semprich, S., Zenz, G., Eds.; Graz University of Technology: Graz, Austria, 2009.

35. FERC (Federal Energy Regulatory Commission). Engineering Guidelines for the Evaluation of Hydropower Projects. Provided by FERC. Available online: https:/ / www.ferc.gov/industries-data/hydropower/dam-safety-and-inspections/eng-guidelines (accessed on 23 December 2020).

36. Moridi, A.; Yazdi, J. Sediment Flushing of Reservoirs under Environmental Considerations. Water Resour. Manag. 2017, 31, 1899-1914. [CrossRef]

37. Guan, M.; Ahilan, S.; Yu, D.; Peng, Y.; Wright, N.G. Numerical Modelling of Hydro-morphological Processes Dominated by Fine Suspended Sediment in a Stormwater Pond. J. Hydrol. 2018, 556, 87-99. [CrossRef] 
38. Soderberg, L. Condit Hydroelectric Power Plant National Register of Historic Places Nomination Form, Washington State Department of Archaeology and Historic Preservation, 23 October 1986. In Hydroelectric Power Plants in Washington State, 18901938; National Register of Historic Places Multiple Property Documentation Form: Baton Rouge, LA, USA, 1988; Volume E3, p. E6.

39. Allen, B.; Engle, R.O.; Zendt, J.S.; Shrier, F.C.; Wilson, J.T.; Connolly, P.J. Salmon and Steelhead in the White Salmon River after the Removal of Condit Dam-Planning Efforts and Recolonization Results. Fisheries 2016, 41, 190-203. [CrossRef]

40. Maser, A. Condit Dam Removal Timelapse Project, Maser Films. 2012. Available online: https://whitesalmontimelapse. wordpress.com/2012/12/03/condit-dam-removal-complete/ (accessed on 23 December 2020).

41. Suwal, N.; Huang, X.; Kuriqi, A.; Chen, Y.; Pandey, K.P.; Bhattari, K.P. Optimisation of Cascade Reservoir Operation Considering Environmental Flows for Different Environmental Management Classes. Renew. Energy 2020, 158, 453-464. [CrossRef]

42. Kuriqi, A.; Pinheiro, A.N.; Sordo-Ward, A.; Garrote, L. Water-Energy-Ecosystem Nexus: Balancing Competing Interests at a Run-of-river Hydropower Plant Coupling a Hydrologic-Ecohydraulic Approach. Energy Convers. Manag. 2020, $223,113267$. [CrossRef]

43. Katopodis, C.; Williams, J.G. The Development of Fish Passage Research in a Historical Context. Ecol. Eng. 2012, 48, 8-18. [CrossRef]

44. Enel (Ente Nazionale per l’Energia Elettrica). Le Dighe di Ritenuta degli Impianti Idroelettrici Italiani: Dighe Appartenti all'Enel di Costruzione Posteriore al 1953 [The Dams of Italian Hydroelectric Plants: Dams Belonging to Enel Built after 1953]; ENEL: Rome, Italy, 1974. (In Italian)

45. Baish, S.K.; David, S.D.; Graf, W.L. The Complex Decisionmaking Process for Removing Dams. Environ. Sci. Policy Sustain. Dev. 2002, 44, 20-31. [CrossRef]

46. Johnson, S.E.; Graber, B.E. Enlisting the Social Sciences in Decisions about Dam Removal. BioScience 2002, 52, 731-738. [CrossRef] 